\title{
Sourcing technological knowledge through corporate acquisition: Evidence from an international sample of high technology firms ${ }^{i s}$
}

\author{
Panos Desyllas ${ }^{a, *}$, Alan Hughes ${ }^{\text {b, }}$ \\ ${ }^{\text {a }}$ Saïd Business School, University of Oxford, Park End Street, Oxford OX1 1HP UK \\ ${ }^{\mathrm{b}}$ Centre for Business Research, Judge Business School, University of Cambridge, Trumpington Street, Cambridge CB2 $1 A G$ UK
}

Available online 14 February 2008

\begin{abstract}
We investigate the prevalence of the motive to source technological knowledge externally through corporate acquisition. Drawing on make-or-buy and organizational learning theories, we infer the implications of this explanation for the acquirers' preacquisition innovative characteristics. Using an international sample of 6106 high technology acquisitions during 1984-2000, we assess the contribution of innovative characteristics to the acquisition likelihood. For firms acquiring small private firms and former subsidiaries - but not public targets - the evidence is consistent with three propositions: (1) A firm's commitment to internal R\&D is negatively affected by the decision to acquire; (2) Low R\&D productivity increases the likelihood of acquisition; (3) A large knowledge stock predisposes firms to acquire because they perceive they are capable of selecting and absorbing targets. We conclude that acquisitions of small private firms and former subsidiaries are a viable R\&D strategy to explore a range of potential future innovation trajectories for large public firms.
\end{abstract}

(c) 2008 Elsevier Inc. All rights reserved.

Keywords: Acquisitions; R\&D; Patents

\section{Introduction}

Acquisition activity in the high technology industries of the global economy rose dramatically in the last two decades of the 20th century. An impression of the order of the magnitude of this activity is provided by Inkpen, Sundaram, and Rockwood (2000), who report that acquisitions by firms in computer- and communication-related industries alone accounted for over one-fifth of all US acquisition activity by number, and two-fifths by value during the 1990s. They also report an accelerated trend towards such acquisitions, with their share accounting for nearly $57 \%$ of the $\$ 1.75$ trillion in total assets acquired in the US between January 1998 and June 1999. Almost every multinational corporation engaged in some acquisition activity in recent years, with Siemens and General Electric acquiring as many as 166 and 110 targets respectively during the period from 1984 to 2000 .

\footnotetext{
is The authors gratefully acknowledge financial support from the ESRC/EPSRC under the AIM initiative, and the CBR core grant. They are grateful to the JHTMR anonymous referees for helpful comments. They also thank Mari Sako, Julian Birkinshaw, Michael Hitt, Paul Kattuman, Dennis Mueller, Thomas Powell, Jaideep Prabhu, Phanish Puranam, Marc Ventresca the referees for the 2005 Academy of Management Conference and the CBR paper series and the seminar participants at the Oxford Intellectual Property Research Centre for their suggestions.

* Corresponding author. Tel.: +44 1865 278805; fax: +44 1865288805.

E-mail addresses: pdesyllas@gmail.com (P. Desyllas), alan.hughes@cbr.cam.ac.uk (A. Hughes).

${ }^{1}$ Tel.: +44 1223 765335; fax: +44 1223765336.
} 
This wave of acquisition activity has engendered greater research focus on acquisitions in the high technology sector of the economy. Empirical research to date has focused on the impact of high technology acquisitions on the subsequent innovation performance (Hitt, Hoskisson, Ireland, \& Harrison, 1991; Ahuja \& Katila, 2001; Cassiman, Colombo, Garonne, \& Veugelers, 2005; Prabhu, Chandy, \& Ellis, 2005) or market value (Kohers \& Kohers, 2000, 2001; Benou \& Madura, 2005; Ragozzino, 2006) of the acquirer. The acquisition impact on performance has been conditioned on factors such as the business, organizational and technological fit between the acquirer and the acquired firms (Ahuja \& Katila, 2001; Cassiman et al., 2005; Prabhu et al., 2005), the nature of knowledge that is to be transferred (Bresman, Birkinshaw, \& Nobel, 1999), the retention of key personnel (Ernst \& Vitt, 2000; Ranft \& Lord, 2000) and the acquisition implementation process (Capron \& Mitchell, 1998; Ranft \& Lord, 2002; Puranam, Singh, \& Zollo, 2006). In many of these studies, it is implicitly or explicitly assumed that the key acquisition driver is the motive to learn from knowledge sources beyond the boundaries of the firm.

However, there has been limited research on the prevalence of this motive among the thousands of acquisition deals that occur each year compared with alternative explanations, such as the realization of synergies arising from economies of scale and scope and market power or the elimination of inefficiencies in the market for corporate control. There are a few notable exceptions that have touched on this issue. Chakrabarti, Hauschildt, and Suverkrup (1994) report evidence from a survey that 24 of the 86 sample acquirers that made an acquisition during the period 1978-1987 had been primarily motivated by the desire to access new technological knowledge. Blonigen and Taylor (2000) find, using regression analysis and a sample of 531 US electronic and electrical equipment acquisitions during the period 1985-1993, that acquirers had a significantly lower R\&D-intensity compared with non-acquirers. They argue that firms in this industry choose between organic growth by internal R\&D and external growth through acquisitions. A recent study on the importance of the motive to source knowledge in pursuing equity investment suggests that this motive is particularly present in industries with weak intellectual property protection, with high technological ferment and where complementary distribution capability is important (Dushnitsky \& Lenox, 2005).

The present study attempts to enhance our understanding of the incidence of high technology acquisitions by assessing empirically the prevalence of the motive to source technological knowledge externally through corporate acquisition. We argue that, to the extent that high technology firms rely on corporate acquisitions as an external sourcing strategy of technological knowledge, this will be reflected in the pre-acquisition innovative characteristics of the acquirers. Drawing on make-or-buy and organizational learning theories, we develop three complementary hypotheses about the acquirers' innovative characteristics. These characteristics involve a firm's commitment to internal R\&D (measured by the ratio of R\&D expenditure to total assets), the R\&D productivity of the firm's assets (measured by successful patent applications per \$million of total assets), and the firm's accumulated stock of knowledge (measured by a firm's patent stock).

Our first hypothesis is based on a particular interpretation of the make-or-buy approach, which views managers of high technology firms as choosing between either investing in in-house R\&D, or sourcing technological knowledge externally through the acquisition of innovative firms (e.g. Blonigen \& Taylor, 2000). Hence, a negative relationship is hypothesized between a firm's commitment to internal R\&D and the acquisition likelihood. The second hypothesis is rooted in the distinction between explorative and exploitative learning (March, 1991). It is argued that acquisitions can be used as a remedy to the inertia and rigidity resulted in by the ongoing exploitation of a firm's existing knowledge base (Vermeulen \& Barkema, 2001). Hence, a negative relationship is hypothesized between the R\&D productivity of a firm's assets and the acquisition likelihood. The third hypothesis is based on the notion of absorptive capacity which implies that the accumulated stock of knowledge of a firm enables it to identify, assimilate and exploit knowledge from the environment (Cohen \& Levinthal, 1989; Makadok, 2001). It is argued that a large stock of knowledge will predispose firms to undertake acquisition because they perceive that they have the necessary absorptive capacity to identify appropriate targets and to fully exploit their innovative potential. Hence, a positive relationship is hypothesized between a firm's knowledge stock and the acquisition likelihood.

These hypotheses are tested using a unique dataset covering a maximum of 6106 acquisitions of public or private firms and former subsidiaries by publicly traded firms in the major industrial economies during the period 1984-2000. The dataset is rich in geographical and industrial diversity and compares favorably with the samples of previous studies (e.g. Hall, 1988, 1999; Blonigen \& Taylor, 2000). By focusing on high technology acquiring firms, we ensure that the generation and commercial exploitation of technological knowledge is an important element in a firm's strategy. In this way, we avoid problems that often arise in studies that use aggregate data from a wide cross-section of industries, since there might exist a differing relationship between acquisitions and innovation activity for high-tech and non-high-tech 
firms (e.g. Porrini, 2004). Finally, our analysis accounts for an increased awareness that acquisitions of large public targets might represent a qualitatively different phenomenon from those of relatively small private firms and former subsidiary units (Ang \& Kohers, 2001; Fuller, Netter, \& Stegemoller, 2002; Conn, Cosh, Guest, \& Hughes, 2005). Arguments drawing on approaches that emphasize the relative strengths of different organizational forms in the innovation process (Williamson, 1975; Zenger, 1994) — such as the entrepreneurial spirit of start-ups versus the financial resources of large firms - suggest that the motivation of sourcing technological knowledge through acquisition is likely to hold more strongly for acquisitions of relatively small private targets and former subsidiaries than for acquisitions of public targets. We, therefore, test the robustness of our findings to the two groups of acquisitions.

The remainder of this paper is organized as follows. The next section develops the theoretical background for the study and the specific hypotheses. This is followed by a section describing the dataset and the methodology employed. Then, the empirical results from the analysis are presented. The final section summarizes the main findings and discusses their implications.

\section{Theory and hypotheses}

The R\&D strategy of firms can be seen as a process of making appropriate choices about R\&D investments in order to build the required knowledge stocks (Dierickx \& Cool, 1989). However, the appropriate strategies for building knowledge stocks need not be constrained to in-house R\&D. Alternative strategies can be adopted that offer firms access to externally generated knowledge, such as a corporate acquisition. Despite well-documented integration difficulties following acquisitions (Haspeslagh \& Jemison 1991; Chaudhuri \& Tabrizi, 1999; Ranft \& Lord, 2000; Puranam, Singh, \& Zollo, 2003; Zollo \& Singh, 2004), an acquisition can overcome the problems of asset interconnectedness and social embeddedness of technological knowledge that can hinder knowledge absorption in piecemeal strategies, such as in-licensing or strategic alliances (Dierickx \& Cool, 1989; Barney, 1991; Steensma \& Fairbank, 1999; Fey \& Birkinshaw, 2005). We focus on three different theoretical approaches in order to explain the reasons that can motivate firms to use corporate acquisitions as a substitute for in-house innovation. In the light of these approaches, we discuss implications for the pre-acquisition innovative characteristics of the acquirers.

\subsection{The decision to make-or-buy $R \& D$}

Arguments with different theoretical origins suggest that a firm can capture larger benefits by adopting a "make" R\&D strategy (in-house R\&D investment) relative to a "buy" R\&D strategy (e.g. contract research or licensing agreement). Taking a knowledge-based view of the firm, it can be argued that firms provide the infrastructure for more efficient coordination, communication, and learning than what can be achieved through market transactions (Kogut \& Zander, 1992, 1996). On this view, the "make" strategy of R\&D is the most efficient option for firms operating in knowledge-intensive environments. Drawing on the transaction cost economics approach, the "make" strategy is again the most efficient option since two attributes of the R\&D process tend to make the "buy" strategy problematic (Williamson, 1975, 1979, 1981). First, the conduct of R\&D involves a high degree of uncertainty. This is mainly the result of difficulties in the definability of the work involved and the predictability of the research outputs in terms of their nature, significance and timing (Odagiri, 2003). Second, it often requires transaction-specific investments in not easily redeployable assets (e.g. site-, physical- or human capital-specificity). Thus, market relationships are subject to the danger of opportunistic behavior by the parties involved. These factors make the writing and enforcement of an $R \& D$ contract a highly costly process.

However, the make-or-buy dilemma takes a different content once the possibility of sourcing externally technological knowledge through corporate acquisition is accounted for. Then, the make-or-buy theory views managers of high technology firms as choosing between organic growth with in-house R\&D or external growth through the acquisition of technological knowledge by taking the majority control over other organizations (Blonigen \& Taylor, 2000). This is an external sourcing strategy, but the transfer of ownership reduces the dangers of moral hazard, at least once the acquisition has been "successfully" completed. In this perspective, the acquisition of firms with valuable technological knowledge can be a less risky and a faster way of exploiting commercially new knowledge (Dierickx \& Cool, 1989; Chakrabarti et al., 1994; Francis \& Smith, 1995). Cisco Systems represents one of the best known examples of high-tech acquisition programs involving persistent acquisitions of high technology start-ups. 
These acquisitions were explicitly seen by Cisco as offering opportunities for access to new technologies (Holloway, Wheelwright, \& Tempest, 2004).

Although firms, particularly the large ones, are likely to follow a mixture of sourcing strategies (Arora \& Gambardella, 1990; Brown \& Eisenhardt, 1997; Veugelers \& Cassiman, 1999; Odagiri, 2003), there are reasons to expect some kind of substitutability between in-house R\&D investments and external sourcing of technological knowledge through acquisitions. First, it is argued that, because firms have a limited pool of financial resources available, a trade-off is likely to exist between investments in acquisitions and investments in other areas, such as R\&D (Hitt et al., 1991). Second, because acquisitions require substantial financial resources, which are often covered by excessive amounts of debt, acquiring firms' financial risk increases (Hitt, Hoskisson, \& Ireland, 1990). As a result, managers themselves or risk-averse debt holders with an influence over the firm's management are then more likely to avoid risky investments with long-horizon payback periods involving largely nonredeployable assets, like R\&D (Smith \& Warner, 1979). Finally, planning, negotiating and executing acquisitions tend to absorb a large part of the managers' time and energy and often affect their commitment to in-house R\&D activities (Hitt, Hoskisson, Johnson, \& Moesel, 1996). On the basis of this approach, we hypothesize the existence of a negative relationship between a firm's commitment to internal R\&D and the likelihood that a firm will pursue an acquisition.

Hypothesis 1. The likelihood that a firm will pursue an acquisition at time $t$ will be negatively related to the firm's commitment to internal R\&D at t-1.

\subsection{Explorative learning through acquisitions}

The second theoretical approach is anchored in the organizational learning literature. In a seminal paper, March (1991) argues that organizations, in order to adapt and survive in a changing competitive environment, need to allocate their limited resources so as to strike a balance between exploration of new alternatives and exploitation of existing competencies and technologies. Because of organizational factors, power-political incentives and the fact that the returns from exploitation tend to be relatively more proximate and predictable, it is argued that organizations often prefer step-by-step local learning over the investigation and adoption of novel alternatives (March, 1991; Schildt, Muala, \& Keil, 2005). However, the ongoing exploitation of the existing knowledge and capabilities, even those that make an organization successful in the short-run, eventually hampers the creation of new knowledge and makes the organization simple, rigid and unsuccessful (March, 1991; Leonard-Barton, 1992; Vermeulen \& Barkema, 2001). This can be attributed to two reasons. First, the ongoing exploitation of a firm's technology base is likely to lead to technological exhaustion since most of the possible relationships between a set of components have already been tried (Kim \& Kogut, 1996; Veugelers \& Cassiman, 1999). Second, the refinement and extension of existing competencies and technologies is likely to trap a firm in sub-optimal equilibria (March, 1991). On the contrary, experimenting with novel and emerging technologies can create significant innovations (Ahuja \& Lampert, 2001).

In accordance with these arguments, evidence provided by Makri and Lane (2007) suggests that when entities (industries) experience a diminishing R\&D productivity due to technological maturity, they need and they actually do attempt to broaden their technology trajectories by exploring the area of more theoretical knowledge (science-based innovation). More specifically, the acquisition literature shows that corporate acquisitions can be employed as a means of dealing with low R\&D productivity. Vermeulen and Barkema (2001) argue, and find supporting evidence, that acquisitions can be employed as a means of technological renewal and of avoiding the inertia and simplicity that result from the repeated exploitation of a firm's knowledge base. There is also evidence that a high degree of bilateral resource redeployment between the acquirer and the acquired firms improves R\&D skills, time to market, product quality and product cost (Capron \& Mitchell, 1998; Bresman et al., 1999).

On the basis of this approach, we expect that there will be an enhanced desire to source new knowledge externally through corporate acquisition when the R\&D productivity of a firm's assets is low. ${ }^{2}$ Therefore, we hypothesize the existence of a negative relationship between the R\&D productivity of a firm's assets and the likelihood that a firm will pursue an acquisition.

\footnotetext{
${ }^{2}$ We refer to the R\&D productivity of a firm's assets, rather the productivity of the reported R\&D expenditure, given the evidence that innovative outputs often come as a result of complementary or alternative resources and capabilities such as professional exchanges, investments in or the operation of machinery, tools and equipment, shareholdings in group companies (OECD, 1996).
} 
Hypothesis 2. The likelihood that a firm will pursue an acquisition at time $t$ will be negatively related to the $R \& D$ productivity of the firm's assets at $\mathrm{t}-1$.

\subsection{The capability to select and absorb acquisition targets}

The third theoretical approach homes in on the dual role played by R\&D (Cohen \& Levinthal, 1989). Firms carry out $\mathrm{R} \& \mathrm{D}$ not only in order to innovate, but also to build their knowledge stock so that they develop their "absorptive capacity". This term captures the broader capability to identify, assimilate and use knowledge from the environment (Cohen \& Levinthal, 1989; Arora \& Gambardella, 1994; Chesbrough, 2003).

On this view, we argue that firms with a large stock of knowledge will have superior absorptive capacity and in turn will be more active in acquisitions. A larger knowledge stock can offer a firm an understanding of a larger domain of knowledge. Therefore, this firm will be better positioned relative to competitors to conceive and assess the potential for value creation from combinations with targets coming from a larger pool of firms (Ahuja \& Katila, 2001). Two additional explanations of the link between a firm's knowledge stock and acquisition activity emerge by Makadok's elaboration on absorptive capacity (Makadok, 2001). The first aspect of absorptive capacity is what Makadok calls "resource-picking". This term is used to describe how superior absorptive capacity enables firms to create economic rent by being more effective than their rivals in selecting resources. By analogy, firms with a large knowledge stock will be more capable relative to rivals of scanning the corporate market and selecting the "appropriate" acquisition targets with reference to their needs and strategic objectives. The second aspect of absorptive capacity is what Makadok calls "capability building". This term is used to describe how superior absorptive capacity enables firms to create economic rent by being more effective than their rivals at deploying the combined resources. By analogy, firms with large knowledge stock will be better capable of exploiting the acquired firms' resource base during the acquisition implementation stage (Haspeslagh \& Jemison, 1991; Ranft \& Lord, 2002).

Thus, a large stock of accumulated knowledge will predispose a firm to undertake acquisition because it perceives that it has the necessary absorptive capacity to select suitable targets and to fully exploit their innovative potential. Therefore, our third hypothesis suggests the existence of a positive relationship between the stock of knowledge and the likelihood that a firm will pursue an acquisition.

Hypothesis 3. The likelihood that a firm will pursue an acquisition at time $t$ will be positively related to the firm's knowledge stock at $\mathrm{t}-1$.

\section{Methods}

\subsection{The data}

Acquisitions are defined as deals where the acquiring firm owns less than $50 \%$ of target's voting shares before the takeover and increases its ownership to at least $50 \%$ as a result of the takeover. Our sample consists of high technology acquisitions, which are deals involving acquiring firms with some part of their activity in one of the high-tech industries specified by Hall and Vopel (1996) and whose primary activity is in SIC 28 Chemicals and Allied Products, SIC 35 Industrial and Commercial Machinery and Computer Equipment, SIC 36 Electronics and Electrical Equipment, SIC 37 Transportation Equipment, SIC 38 Measuring, Analyzing and Controlling Instruments; Photographic, Medical and Optical Goods, SIC 48 Communications, SIC 73 Business Services, SIC 87 Engineering, Accounting, Research, Management, and Related Services. ${ }^{3}$ We focus on acquisitions carried out by publicly traded firms and which operate in one of the ten most acquisition-active industrialized countries, namely Australia, Canada, France, Italy, Japan, the

\footnotetext{
${ }^{3}$ These eight 2-digit SIC codes are the ones defined by Hall and Vopel (1996) as high-tech industries with the addition of SIC 73 and 87 . SIC 73 is added to the set of high-tech SICs because many of the firms active in 357 Computer and Office Equipment are often classified as software companies with primary activity in SIC 737 Computer Programming and Data Processing. SIC 87 is added to the set of high-tech SICs because a large number of the companies selected based on Hall and Vopel classification had their primary activity in SIC 873 Research, Development, and Testing Services. "Purely" software firms are excluded from the sample in the first instance, because, in the past, intellectual property rights tended to be secured by copyrights rather than by patents. These restrictions are imposed to avoid the inclusion of large conglomerate companies which are primarily active in non-high-tech industries with just a small proportion of their sales in a high-tech industry.
} 
Netherlands, Sweden, Switzerland, the UK, and the US. ${ }^{4}$ The population of acquisitions comes from Thomson Financial's SDC Platinum, which reports 12,200 completed deals announced during the period from January 1984 to December 2000.

The innovative activity of firms is measured using data on the inputs of the conduct of R\&D (R\&D expenditure) and its output in the form of intellectual property registered as patents. ${ }^{5}$ However, because the distribution of the value of patented inventions is extremely skewed (Scherer, 1997), we also consider for each patent the number of forward citations it receives by subsequent patents to approximate its value. A patent which is cited many times is more likely to be highly valued than a patent which is relatively rarely cited (Griliches, 1990).

Financial data and data on R\&D expenditure were collected from Datastream, Compustat and Global Vantage. Data on patent counts and patent citations were collected from the NBER dataset which includes all the utility patents granted by the US Patent and Trade Office (USPTO) (Hall, Jaffe, \& Trajtenberg, 2001). ${ }^{6}$ Moreover, because firms often register patents under their subsidiaries' names (Bloom \& Van Reenen, 2000), we used Dun \& Bradstreet's "Who owns whom" annual issues to obtain their detailed corporate structure and data were aggregated at the parent firm level.

Combining these databases we construct a unique unbalanced panel dataset covering the period 1984-2000 which consists of innovative and financial characteristics for a total of 2967 firms, including both acquiring and non-acquiring firms. Due to data availability requirements that are imposed from our model, the analysis is conducted on the basis of a total of 2611 firms, including 6106 acquisitions that have been initiated by 1160 firms. These acquisitions include 812 publicly traded targets, 4493 privately held targets and 801 subsidiary units that were divested by their former parent. Because our citation data end in 1997, the citation-weighted patent-based characteristics of acquiring firms can be assessed on the basis of a 4818 acquisitions initiated by 1067 acquiring firms. The fall in the number of acquiring firms included in our analysis introduces some sample selection bias towards larger firms. While the overall median size of all acquiring firms equals 12.3 ( $\mathrm{ln}$ total assets measured in \$1996 thousands), the median size of the 6106 (4818) acquiring firms that are included in the analysis equals 12.8 (12.7). This size imbalance arises from the fact that the firms linked to patent assignees tend to be relatively larger compared with those not linked.

\subsection{The model}

In order to test the hypotheses about the effect of the innovative characteristics of firms on the likelihood to pursue an acquisition, the acquisition probability is modelled as a function of firm characteristics. Because the acquisition incidence in a given year takes strictly non-negative values, we employ a logit and a negative binomial maximum likelihood model to estimate the acquisition probabilities (Greene, 1997; Wooldridge, 2002). Similar estimation methods have been used in previous empirical work (Palepu, 1986; Hall, 1988, 1999; Powell, 1997; Blonigen \& Taylor, 2000). The logit model is attractive due to its simplicity, but because it is a binary response model, it treats similarly firms that undertake a single or multiple acquisitions in a given year. The negative binomial maximum likelihood model tackles this drawback, where the dependent variable is the actual number of acquisitions made. Because acquisition events are often clustered by country, industry and time-period (Mitchell \& Mulherin, 1996; Andrade \& Stafford, 2004), in which case the independence assumption of acquisition events is violated and hence the standard errors are incorrect (Poirier \& Ruud, 1988), year, country and industry dummies are added to the set of our regressors (See Beck, Katz, \& Tucker, 1997). ${ }^{7}$

Given the cross-section and time-series nature of our dataset, we employ panel data estimation methods that allow us to account for some unobserved heterogeneity across firms (Hsiao, 1986; Wooldridge, 2002). We employ the random-

\footnotetext{
${ }^{4}$ German acquiring firms were initially included in the sample but they were eventually dropped because of lack of data (in particular, R\&D expenditures were missing for the population of German firms).

${ }^{5}$ Strictly speaking, patents reflect inventions, i.e. "an idea, a sketch or a model for a new improved device, product, process, or system" rather than innovations, where an innovation "is accomplished only with the first commercial transaction involving the new product, process, system or device" (Freeman, 1982). However, because patents are found to be correlated with innovations (Comanor \& Scherer, 1969; Griliches, 1990), they can be used as proxies for innovative activity. For an overview of the limitations of the use of patents as indicators of inventive and innovative activity see Archibugi (1992) and Pidgeon (1999).

${ }^{6}$ Our study is not the first one to employ US patent data for both US and non-US firms (See Geroski, Van Reenen, \& Samiei, 1996; Bloom \& Van Reenen, 2000). Our analysis controls for the possibility of some "home advantage" bias, since US firms will tend to have a higher propensity to patent in their home-country patent office compared to non-US firms. The latter might tend to register relatively more "important" inventions to the USPTO.

${ }^{7}$ Industry groups are defined at the 2-digit SIC level, with the exception of firms in SIC 283 Drugs which are distinguished from those in SIC 28 (excluding 283), since they are likely to have distinct characteristics, such as a significantly higher R\&D-intensity.
} 
effects approach for two reasons. First, because the fixed-effects estimator causes a considerable fall to the number of firms that are included in the sample over which parameters are estimated. ${ }^{8}$ Second, with the fixed-effects estimator, we cannot control for time-constant factors like the country and the industry in which firms operate. We also employ the simple logit estimator. It is expected to lead to comparable estimates to those of the random-effects estimator if the variance contributed by the panel-level component is small relative to the total variance. Robust standard errors to within-firm serial correlation are calculated, since even if firm-specific effects are uncorrelated with the regressors, the composite errors might be serially correlated due to the presence of a firm-specific effect in each time-period.

\subsection{The variables}

\subsubsection{Dependent variable}

In the logit model, the dependent variable is a binary variable which equals one in the set of firm-year observations in which a firm makes one or more acquisitions and zero otherwise. In the negative binomial maximum likelihood model, the dependent variable is the count of the number of acquisitions carried out by a given firm in a given year.

\subsubsection{Independent variables}

In accordance with our three complementary hypotheses, the acquisition likelihood is modelled as a function of oneyear lagged values of three innovation-related variables. ${ }^{9}$ A firm's commitment to internal R\&D is proxied by its $R \& D$-intensity (See, for example, Hitt et al., 1991; Blonigen \& Taylor, 2000; Hall, 1999). We consider the intensity of $R \& D$ expenditure to account for the large size differences across firms. It is calculated using the ratio of $R \& D$ expenditure to total assets. ${ }^{10}$ The R\&D productivity of a firm's assets is proxied by its Patent-intensity. It is calculated using the ratio of the number of successful patent applications to \$million of total assets (1996 prices). A firm's stock of knowledge is proxied by its Patent Stock. We employ this particular proxy for the knowledge stock rather than of the stock of R\&D expenditure, mainly because the patent series does not suffer from the time discontinuities present in the $R \& D$ expenditure series. Other researchers have suggested that the patent stock is a better proxy for the stock of knowledge on the basis that it represents the success of R\&D programs (e.g. Dushnitsky \& Lenox, 2005). The Patent Stock is calculated using the standard perpetual inventory formula (See Hall, 1990). The patent stock at time $t$ equals last period's patent stock, after depreciation at rate $\delta$ (assumed 15\%) is deducted, plus the number of patents at time $t$.

$$
\text { Patent } \text { Stock }_{t}=(1-\delta) \text { Patent } \text { Stock }_{t-1}+\text { Patents }_{t}
$$

It is transformed in a natural logarithmic $(\ln )$ form in order to reduce its large variance and fulfill the assumptions necessary for the validity of regression inferences. Patent-intensity and the Patent Stock are also calculated using the number of citations received by forward patents, instead of the raw patent count, to account not only for the quantity but also the quality of the patented inventions. However, because the number of forward citations received by a patent can be affected by its technological field, the cohort it belongs to and some truncation bias ${ }^{11}$, we employ the number of "normalized" citations. Following Hall et al. (2001), we divide the number of citations that a given patent received with the average number of citations received by all patents that were applied for in the same year within the same technological classification.

\subsubsection{Control variables}

We control for firm characteristics that are likely to influence both a firm's innovative and acquisition activity. The set of control characteristics consists of proxies for firm size, economic performance and the availability of financial resources. The evidence from previous studies is that the acquisition probability tends to be positively related to firm size, economic performance and internal financial resources (Hall, 1988, 1999; Blonigen \& Taylor, 2000; Andrade \&

\footnotetext{
${ }^{8}$ This is because the fixed-effects estimator procedure requires some variation in the outcome for each firm across time, and considers only firms for which data on regressors are available for more than a single year.

${ }^{9}$ By taking the lagged values of the independent and control variables we avoid endogeneity problems and possible biases arising from different acquisition accounting methods and financial statement consolidation.

${ }^{10}$ Some studies calculate R\&D-intensity as the ratio of R\&D-expenditure to sales. Because we proxy firm size by total assets, we use the same variable in the denominator of the ratio for consistency reasons.

${ }^{11}$ Patents applied for closer to the right-end of our dataset will have a smaller "opportunity" to be cited in subsequent patents.
} 
Stafford, 2004; Gugler, Mueller, Yurtoglu, \& Zulehner, 2004). We consider 1-year lagged values of the controls and all financial variables are expressed in constant 1996 prices using the US GDP deflator.

The variable Total Assets is employed to proxy for firm size. It is measured by the natural logarithm of total assets in $\$ 1996$ thousands. We have chosen this specific size measure, because it has the best coverage among all the alternatives considered (sales, number of employees, net assets). Previous studies employing a similar size proxy include Powell (1997) and Blonigen and Taylor (2000).

The economic performance is proxied by two variables. ${ }^{12}$ Total Asset Growth is employed to proxy for corporate growth. It is calculated as the annual growth in total assets. Operating Return is employed to proxy for firm profitability. It is calculated using the ratio of earnings before interest taxation, depreciation and amortization (EBITDA) to total assets.

The financial status of firms is proxied by leverage and liquidity. Leverage reflects the financial risk faced by a firm which might limit managers' ability to allocate adequate resources to R\&D activity (Smith \& Warner, 1979). It is calculated using the ratio of long-term debt to the book value of common equity. Liquidity is employed as a measure of a firm's ability to meet its short-term obligations from its current assets. It is calculated using the ratio of current assets to current liabilities.

\subsection{Measurement issues}

Table 1 provides descriptive statistics and correlations for all the variables. A first look at the relationship between our independent variables and acquisition activity, reveals that R\&D-intensity and Patent-intensity (raw and citationweighted) are significantly negatively correlated with the acquisition indicator and the number of acquisitions. On the contrary, the Patent Stock (raw and citation-weighted) is significantly positively correlated with the two acquisition variables.

In order to account for idiosyncrasies (skewedness, missing observations, non-linearity) of some of the variables additional adjustments have been adopted (See Hall, 1999). First, we assume that R\&D-intensity is immaterial whenever R\&D-expenditure is not reported but data on the other economic and innovation variables are available. Therefore, a dummy is employed for missing R\&D values (Dummy No $R \& D$ ), which equals one when R\&D is missing and R\&D-intensity is set equal to zero. We found that the regression results are qualitatively identical with and without this normalization, and hence we report results with the normalization. Second, a dummy variable is employed for firms with no patent activity (Dummy No Patents), to distinguish between firms with some versus no patents. Third, a dummy variable is employed for very negative operating returns (Dummy Op. Return Negative), that is for EBITDA losses of more than half the firm's total assets, in which case the continuous variable is set to zero.

\section{Results}

\subsection{Innovation characteristics and acquisition likelihood}

Table 2 provides the estimated coefficients for the simple logit, the random-effects logit and the random-effects negative binomial models. Two versions of each model are reported, one where patents are measured using raw patent counts and one where patents are measured using citation-weighted patents. The estimates from the raw patent regressions are based on 24021 observations of 2611 firms including 6106 acquisitions. The estimates from the citation-weighted patent regressions are based on 20545 observations of 2453 firms including 4818 acquisitions. As can be seen from the random-effects logit and negative binomial models, the likelihood ratio test of the null hypothesis that the panel-level variance component $(\rho)$ is unimportant is rejected ( $p<0.001$ in all cases). Yet, the estimates and the corresponding standard errors from the three estimators are quite close. The Wald tests reject the null hypothesis that the explanatory variables of the model are jointly zero ( $p<0.001$ in all cases). The value of the pseudo $R$-squared is satisfactory and comparable to that of similar studies (e.g. Gugler et al., 2004).

\footnotetext{
${ }^{12}$ We also experimented in the analysis with the inclusion of Tobin's $q$ as an indicator of a firm's intangible value and a measure of the value of technological assets. This made no material difference to the results reported in the paper. The drawback of the inclusion of Tobin's $q$ are that (1) it led to a large fall in the observations because it cannot be calculated for a number of non-US firms; and (2) it might lead to biased estimates of R\&D- and patent-based variables due to statistical correlation with $R \& D$ and patents and possible measurement error.
} 
Table 1

Descriptive statistics and correlation matrix

\begin{tabular}{|c|c|c|c|c|c|c|c|c|c|c|c|c|c|c|c|c|c|c|}
\hline & Variable & Obs. & Mean & S.D. & Min & Max & 1 & 2 & 3 & 4 & 5 & 6 & 7 & 8 & 9 & 10 & 11 & 12 \\
\hline 1 & Acquisition indicator & 24021 & 0.153 & 0.360 & 0.000 & 1.000 & 1.00 & & & & & & & & & & & \\
\hline 2 & Acquisition No. & 24021 & 0.254 & 0.810 & 0.000 & 21.000 & 0.74 & 1.00 & & & & & & & & & & \\
\hline 3 & R\&D-intensity (un-adjusted) & 21880 & 0.103 & 0.182 & 0.000 & 1.784 & -0.05 & -0.05 & 1.00 & & & & & & & & & \\
\hline 4 & R\&D-intensity & 24021 & 0.094 & 0.177 & 0.000 & 1.784 & -0.05 & -0.05 & 1.00 & 1.00 & & & & & & & & \\
\hline 5 & Patent-intensity & 24021 & 0.032 & 0.118 & 0.000 & 1.298 & -0.04 & -0.04 & 0.28 & 0.27 & 1.00 & & & & & & & \\
\hline 6 & Patent-intensity (Cite-wtd) & 20545 & 0.045 & 0.191 & 0.000 & 2.237 & -0.03 & -0.03 & 0.22 & 0.22 & 0.73 & 1.00 & & & & & & \\
\hline 7 & Patent stock (ln) & 24021 & 0.087 & 4.711 & -9.210 & 7.698 & 0.18 & 0.17 & 0.01 & 0.03 & 0.13 & 0.12 & 1.00 & & & & & \\
\hline 8 & Patent stock (Cite-wtd) (ln) & 20545 & -0.407 & 5.190 & -9.210 & 7.671 & 0.18 & 0.17 & -0.01 & 0.02 & 0.14 & 0.15 & 0.95 & 1.00 & & & & \\
\hline 9 & Total assetss $(\ln )$ & 24021 & 11.761 & 2.344 & 5.114 & 17.529 & 0.23 & 0.25 & -0.40 & -0.37 & -0.24 & -0.20 & 0.39 & 0.38 & 1.00 & & & \\
\hline 10 & Total asset growth & 24021 & 0.272 & 1.184 & -0.782 & 15.083 & 0.01 & 0.01 & 0.00 & 0.00 & 0.04 & 0.06 & -0.05 & -0.05 & -0.09 & 1.00 & & \\
\hline 11 & Operating return & 24021 & -0.005 & 0.441 & -4.858 & 0.539 & 0.11 & 0.10 & -0.71 & -0.69 & -0.24 & -0.18 & 0.05 & 0.07 & 0.40 & 0.01 & 1.00 & \\
\hline 12 & Leverage & 24021 & 0.593 & 2.394 & -14.957 & 22.605 & -0.01 & -0.01 & -0.09 & -0.08 & -0.04 & -0.03 & -0.01 & -0.01 & 0.14 & -0.02 & 0.04 & 1.00 \\
\hline 13 & Liquidity & 24021 & 3.312 & 4.024 & 0.046 & 36.217 & -0.04 & -0.05 & 0.08 & 0.08 & 0.09 & 0.07 & -0.05 & -0.05 & -0.24 & 0.28 & -0.01 & -0.09 \\
\hline
\end{tabular}

Correlations in bold font are statistically significant $(p<0.01)$.

R\&D-intensity is reported both un-adjusted and adjusted where missing observations are assumed to be zero if data on all other variables are available. 
Table 2

Parameter estimates of the logit and negative binomial regressions

\begin{tabular}{|c|c|c|c|c|c|c|}
\hline \multirow[t]{2}{*}{ Regressor } & \multicolumn{2}{|l|}{ Logit } & \multicolumn{2}{|l|}{ Logit random effects } & \multicolumn{2}{|c|}{ Negative binomial random effects } \\
\hline & Patents & Cite-wtd patents & Patents & Cite-wtd patents & Patents & Cite-wtd patents \\
\hline R\&D-intensity & $-0.6465 * *(0.3127)$ & $-1.0582 * * *(0.3724)$ & $-0.5008 *(0.2957)$ & $-0.7588^{* *}(0.3537)$ & $-0.5147 * *(0.2494)$ & $-0.6648 * *(0.2956)$ \\
\hline Dummy no R\&D & $-0.0336(0.107)$ & $0.0147(0.1139)$ & $-0.0832(0.1129)$ & $-0.0203(0.1188)$ & $-0.0498(0.085)$ & $-0.0025(0.0904)$ \\
\hline Patent-intensity & $-0.3758(0.3393)$ & $-0.4594 * *(0.2249)$ & $-0.0877(0.3546)$ & $-0.3114(0.2204)$ & $-0.1133(0.309)$ & $-0.2939(0.1929)$ \\
\hline Dummy no patents & $-0.1346^{* *}(0.0674)$ & $-0.1924 * * *(0.0718)$ & $-0.0584(0.07)$ & $-0.1325 *(0.0759)$ & $-0.0597(0.0509)$ & $-0.1259^{* *}(0.0567)$ \\
\hline Patent stock $(\ln )$ & $0.0372 * * *(0.0101)$ & $0.0294 * * *(0.0096)$ & $0.0485 * * *(0.0097)$ & $0.0353 * * *(0.0092)$ & $0.0354 * * *(0.0074)$ & $0.0230 * * *(0.0073)$ \\
\hline Total assets $(\ln )$ & $0.3656^{* * *}(0.0209)$ & $0.3537 * * *(0.0222)$ & $0.4103^{* * *}(0.0215)$ & $0.4007^{* * *}(0.0229)$ & $0.3311 * * *(0.0164)$ & $0.3254 * * *(0.0178)$ \\
\hline Total asset growth & $0.0772 * * *(0.0164)$ & $0.0705^{* * *}(0.0176)$ & $0.0548 * * *(0.0207)$ & $0.0436^{*}(0.023)$ & $0.0473 * * *(0.0158)$ & $0.0332 *(0.0181)$ \\
\hline Operating return & $1.6752 * * *(0.2039)$ & $1.5439 * * *(0.2185)$ & $2.1353 * * *(0.2014)$ & $1.9855^{* * *}(0.2229)$ & $1.7395 * * *(0.155)$ & $1.6803 * * *(0.1762)$ \\
\hline Dummy op. return negative & $0.0079(0.1489)$ & $0.1721(0.1636)$ & $-0.0897(0.1636)$ & $0.0666(0.1821)$ & $-0.0988(0.141)$ & $0.0269(0.1568)$ \\
\hline Leverage & $-0.0101(0.0088)$ & $-0.0142(0.0104)$ & $-0.0172(0.0112)$ & $-0.0228 *(0.0128)$ & $-0.0140 *(0.008)$ & $-0.0139(0.0092)$ \\
\hline Liquidity & $-0.0047(0.0074)$ & $-0.0045(0.0078)$ & $0.0046(0.0083)$ & $0.0053(0.0088)$ & $0.0065(0.0068)$ & $0.0067(0.0073)$ \\
\hline Constant & $-5.8459^{* * *}(0.3178)$ & $-5.2151^{* * *}(0.3369)$ & $-6.8501 * * *(0.3327)$ & $-6.1924 * * *(0.3491)$ & $-3.5179 * * *(0.2622)$ & $-3.0850 * * *(0.287)$ \\
\hline Year dummies (LR test) & $552.2 * * *$ & $527.2^{* * *}$ & $520.8^{* * *}$ & $498.5^{* * *}$ & $642.6^{* * *}$ & $624.1 * * *$ \\
\hline Industry dummies (LR test) & $1223.7^{* * *}$ & $998.0^{* * *}$ & $547.1 * * *$ & $475.7 * * *$ & $523.1 * * *$ & $472.4 * * *$ \\
\hline Country dummies (LR test) & $225.8^{* * * *}$ & $186.5 * * *$ & $101.2 * * *$ & $87.1 * * *$ & $87.9 * * *$ & $74.9 * * *$ \\
\hline Observations & 24021 & 20545 & 24021 & 20545 & 24021 & 20545 \\
\hline Firms & 2611 & 2453 & 2611 & 2453 & 2611 & 2453 \\
\hline Acquisitions & 6106 & 4818 & 6106 & 4818 & 6106 & 4818 \\
\hline Wald $X^{2}$ test & $1605.4^{* * *}$ & $1452.8^{* * *}$ & $1586.5^{* * *}$ & $1349.2^{* * * *}$ & $2020.6^{* * *}$ & $1726.3^{* * * *}$ \\
\hline Log likelihood & -8263.8 & -6974.6 & -7851.3 & -6660.8 & -11451.5 & -9482.4 \\
\hline Pseudo $R^{2}$ & 0.20 & 0.19 & & & & \\
\hline Likelihood ratio test of $p$ & & & $825.1 * * *$ & $627.7 * * *$ & $1211.6^{* * *}$ & $910.0 * * *$ \\
\hline
\end{tabular}

$* * * p<0.01 ; * * p<0.05 ; * p<0.1$.

The dependent variable in the logit models is a binary variable which equals one for firm-year observations in which a firm makes one or more acquisitions and zero otherwise; in the negative binomial maximum likelihood model it is the count of the number of acquisitions. Standard errors are in parentheses. Robust standard errors to within-firm serial correlation are reported for the logit model. The base country is the US, the base industry SIC 283. The base year is 2000 in the raw patent regressions and 1998 in the citation-weighted regressions. 
In accordance with Hypothesis 1, which predicts that the acquisition likelihood will be negatively related to a firm's commitment to internal $R \& D$, we consistently find that acquiring firms have a statistically significant low R\&Dintensity before acquisition. The significance level varies from $1 \%$ in the logit regression with citation-weighted patents to $10 \%$ in the logit random effects regression with raw patent counts. We find only weak support for Hypothesis 2 , which predicts that the acquisition likelihood will be negatively related to the R\&D productivity of a firm's assets. Although we obtain a constantly negative coefficient of Patent-intensity, it is statistically significant only in the logit regression with citation-weighted patents $(p<0.05)$. At the same time there is evidence that the acquiring firms are more likely to have at least some patenting activity before acquisition, with the coefficient of the Dummy No Patents being statistically significant in four out of the six regressions. Hypothesis 3, which predicts that the acquisition likelihood will be positively related to a firm's knowledge stock, is strongly supported by the results. The acquiring firms tend to have a significantly larger Patent Stock in all six regressions $(p<0.01$ in all cases).

In relation to the control variables, we consistently find significantly positive coefficients for the acquiring firms' Total Assets, Total Asset Growth and Operating Return, while there is some evidence that acquiring firms have significantly low Leverage. In other words, acquirers tend to be large firms with a good performance record and a large capacity to raise additional debt to finance acquisitions. As can be seen from the likelihood ratio tests reported at the bottom of the table, the set of year, country and industry dummies are jointly statistically significant.

\subsection{Robustness checks: Acquisitions of public versus non-public targets}

The inclusion of acquisitions of both public and non-public targets (private firms and former subsidiaries) in the analysis of this paper requires some attention, as we believe there might be important quantitative and qualitative differences. A notable difference between acquisitions of public versus non-public targets is their size. The median acquisition value of public targets equals $\$ 133.1 \mathrm{~m}$, whilst the median acquisition value of non-public targets equals $\$ 13.6$ m (Mann-Whitney test $p<0.01)$.

There are arguments on the basis of which it can be argued that acquisitions motivated by the desire to source new knowledge externally may primarily be directed towards relatively small private firms and former subsidiaries. As far as private targets are concerned, Makri and Lane's (2007) finding, that entities (industries) tend to respond to low R\&D productivity by focusing on more theoretical, scientific knowledge, implies that firms experiencing low R\&D productivity of their assets are relatively more likely to look for science-based start-ups (e.g. university spinouts). Also, Williamson's (1975) systems approach of the innovation process implies that the relative strengths of small firms are their behavioral characteristics (e.g. entrepreneurial spirit), while those of large firms lie mostly in resources (e.g. financial basis and commercialization capabilities). Similarly, Zenger (1994) suggests that small firms tend to be relatively more efficient in $R \& D$ due to the existence of organizational diseconomies of scale in the conduct of R\&D. Williamson concludes that efficiency requires that the initial development and market testing to be performed by small firms, the successful developments then to be acquired, possibly through licensing or takeover, for subsequent marketing by large firms.

In the case of acquisitions of former subsidiaries, it has been argued that divestments often occur when business units require substantial $R \& D$ and capital investments for their innovation potential to be exploited that the parent firms are unwilling or unable to make (Grandstrand \& Sjolander, 1990; Weston, Chung, \& Siu, 1998; Parhankangas \& Arenius, 2003). This is the case, particularly when business units no longer fall inside their parent firms' strategic orientation.

Therefore, we investigate the validity of our hypotheses for acquisitions of public versus non-public targets. We employ a multinomial logit model, where the dependent variable takes on three different values, depending on whether a firm makes no acquisitions in a year, acquires at least one public target ${ }^{13}$, or acquires non-public targets only. The results shown in Table 3 are reported in terms of marginal effects evaluated at the averages of the regressors, since in

\footnotetext{
13 This group also includes firm-year observations where, apart from acquisitions of public firms, possibly non-public targets are acquired. The underlying assumption is that acquisitions of public targets are likely to dominate in significance acquisitions of non-public firms, since the transaction value of the former is about ten times larger than the value of the latter. We also discriminated between observations in which the acquiring firm acquires public targets only and both public and non-public targets, but we found that these two groups of acquiring firms have similar characteristics.
} 
Table 3

Parameter estimates of the multinomial logit regressions

\begin{tabular}{|c|c|c|c|c|}
\hline \multirow[b]{2}{*}{ Regressor } & \multicolumn{2}{|l|}{ Patents } & \multicolumn{2}{|l|}{ Cite-wtd patents } \\
\hline & $\begin{array}{l}\text { Acquisitions of non-public } \\
\text { targets }\end{array}$ & $\begin{array}{l}\text { Acquisitions of public } \\
\text { targets }\end{array}$ & $\begin{array}{l}\text { Acquisitions of non-public } \\
\text { targets }\end{array}$ & $\begin{array}{l}\text { Acquisitions of public } \\
\text { targets }\end{array}$ \\
\hline R\&D-intensity & $-0.0687 * * *(0.3178)$ & $0.0090 *(0.0047)$ & $-0.0821 * * *(0.3178)$ & $-0.0017(0.0068)$ \\
\hline Dummy no R\&D & $0.0002(0.0079)$ & $-0.0025(0.0021)$ & $0.0033(0.0081)$ & $-0.0015(0.0021)$ \\
\hline Patent-intensity & $-0.0283 *(0.0170)$ & $-0.0081(0.0106)$ & $-0.0345^{* *}(0.0153)$ & $-0.002(0.006)$ \\
\hline Dummy no patents & $-0.0095 *(0.005)$ & $-0.0023 *(0.0014)$ & $-0.0146^{* * *}(0.0052)$ & $-0.0011(0.0016)$ \\
\hline Patent stock (ln) & $0.0029^{* * *}(0.0007)$ & $6.99 \mathrm{E}-05(0.0002)$ & $0.0020^{* * *}(0.0007)$ & $0.0002(0.0002)$ \\
\hline Total assets $(\ln )$ & $0.0213 * * *(0.0017)$ & $0.0065^{* * *}(0.0005)$ & $0.0207 * * *(0.0017)$ & $0.0058^{* * *}(0.0005)$ \\
\hline Total asset growth & $0.0054^{* * *}(0.0012)$ & $0.0007^{* * *}(0.0003)$ & $0.0046^{* * *}(0.0013)$ & $0.0008^{* *}(0.0003)$ \\
\hline Operating return & $0.1119 * * *(0.0149)$ & $0.0191^{* * *}(0.0043)$ & $0.0974 * * *(0.0153)$ & $0.0199 * * *(0.0048)$ \\
\hline Dummy op. return negative & $-0.0004(0.0108)$ & $0.0007(0.004)$ & $0.0097(0.0116)$ & $0.0029(0.0048)$ \\
\hline Leverage & $-0.0005(0.0007)$ & $-0.0003(0.0002)$ & $-0.0007(0.0007)$ & $-0.0004(0.0003)$ \\
\hline Liquidity & $-0.0006(0.0005)$ & $0.0003 * *(0.0001)$ & $-0.0005(0.0005)$ & $0.0002(0.0002)$ \\
\hline Constant & $-0.3730 * * *(0.0267)$ & $-0.1106^{* * *}(0.0083)$ & $-0.3237 * * *(0.0264)$ & $-0.0999 * * *(0.0084)$ \\
\hline Year dummies (LR test) & \multicolumn{2}{|c|}{$642.2 * * *$} & \multicolumn{2}{|c|}{$604.0^{* * *}$} \\
\hline Industry dummies (LR test) & \multicolumn{2}{|c|}{$1228.9^{* * *}$} & \multicolumn{2}{|c|}{$999.1 * * *$} \\
\hline Country dummies (LR test) & \multicolumn{2}{|c|}{$293.1 * * *$} & \multicolumn{2}{|c|}{$245.6^{* * *}$} \\
\hline Observations & \multicolumn{2}{|c|}{24021} & \multicolumn{2}{|c|}{20545} \\
\hline Firms & 2611 & & 2453 & \\
\hline Acquisitions & 6106 & & 4818 & \\
\hline$X^{2}$ test & 1641.7 & & 1463.9 & \\
\hline Log likelihood & -9867 & & -8261 & \\
\hline Pseudo $R^{2}$ & 0.18 & & 0.18 & \\
\hline
\end{tabular}

$* * * p<0.01 ; * * p<0.05 ; * p<0.1$.

The dependent variable takes on three different values, depending on whether a firm makes no acquisitions in a year, acquires at least one public target, or acquires non-public targets only. Estimated coefficients are reported in terms of marginal effects evaluated at the averages of the regressors. See notes to Table 2.

multinomial logit models the direction of the effect of each regressor cannot be assessed simply by the sign of its estimated coefficient.

The results from the regressions for acquisitions of non-public targets confirm and strengthen our earlier findings. There is clear evidence that acquiring firms have significantly low R\&D-intensity (Hypothesis $1 ; p<0.01$ in both regressions), low Patent-intensity (Hypothesis 2; $p<0.10$ and $p<0.05$ in the raw and citation-weighted patent regressions respectively) and a significantly large Patent Stock (Hypothesis $3 ; p<0.01$ in both regressions). On the contrary, we fail to find evidence in favor of any of our hypotheses for firms acquiring public targets. The only similarity between the two groups of acquiring firms is that both seem to have some patent activity before acquisitions. Interestingly, contrary to Hypothesis 1 , there is some evidence that the acquirers of public targets tend to have somewhat high R\&D-intensity ( $p<0.10$ in the regression with raw patents). Overall, the results about acquisitions of public targets can be interpreted as evidence that in such acquisitions other motives prevail, such as to rationalize and reorganize R\&D investment programs by firms which are already highly R\&D-intensive. With respect to the control variables, the results confirm our earlier findings and both groups of acquiring firms tend to be relatively large, growing and profitable.

In order to assess the economic significance of each of the three key innovative firm characteristics, we examine how the acquisition probability changes given a marginal movement in each of these variables. A marginal change is assumed to be equal to the standard deviation of each variable and the direction of the change is taken to accord with our hypotheses. We focus on the innovative characteristics of the firms acquiring private targets and former subsidiaries (See the regression with citation-weighted patents in Table 3). A one standard deviation decrease in R\&D-intensity $(-0.163)$ increases the probability of making acquisitions by 0.013 (marginal effect: $-0.082 \times$ marginal change: $-0.163)$. If the acquisition probability had previously been at its sample mean value $(0.122)$, the probability is increased by $11 \%$. For a firm with positive patenting activity, a marginal decrease in the citation-weighted Patentintensity $(-0.191)$ leads to an increase in the acquisition probability by 0.007 , or by $5.4 \%$. Finally, a marginal increase in the Patent Stock (5.19) increases the probability of making acquisitions by 0.001 or by $8.5 \%$. Therefore, a 
hypothetical firm whose innovative characteristics change simultaneously towards the direction predicted by our three hypotheses has an almost $25 \%$ higher probability to acquire a private target or a former subsidiary.

\section{Discussion and conclusions}

This paper investigated empirically whether the innovative profile of acquirers is consistent with the view that high technology firms use acquisitions as a means of sourcing externally technological knowledge. An important finding of this study is that it is only the firms acquiring privately held targets and former subsidiary units - and not those acquiring public targets - that are characterized by an innovative profile that is consistent with the three complementary hypotheses developed.

First, we find strong evidence supporting the hypothesis that the acquisition likelihood is negatively related to a firm's commitment to internal R\&D, which is proxied empirically by R\&D-intensity (Hypothesis 1). This finding is in accordance with the make-or-buy theory that views managers of high technology firms as choosing between either investing in in-house $R \& D$, or sourcing technological knowledge externally through acquisitions. The finding that this explanation holds only for acquirers of non-pubic targets has implications for earlier empirical work. Blonigen and Taylor (2000) find that R\&D-intensity has a negative effect on the acquisition likelihood using a sample of 531 acquisitions by US electronic and electrical equipment firms during the period 1985-1993. However, our results suggest that interpretations of Blonigen and Taylor's analysis should bear in mind the possibility of aggregation bias as a result of not discriminating between acquisitions of public and non-public targets. ${ }^{14}$ The normal or high R\&Dintensity we find for acquirers of public targets is inconsistent with the evidence provided by Hall $(1988,1999)$. Using a sample of a maximum of 861 US manufacturing acquisitions from 1976 to 1995 , she finds that acquirers tend to have low or normal R\&D-intensity. We believe that this difference reflects the fact that her sample extends across all the manufacturing industries, including the non-high-tech ones.

Second, we find significant evidence supporting the hypothesis that the acquisition likelihood is negatively related to the R\&D productivity of a firm's assets, which is proxied empirically by Patent-intensity (Hypothesis 2). Therefore, there exists an enhanced desire to source technological knowledge through acquisitions driven by a declining R\&D productivity of a firm's assets. This view is consistent with the theoretical arguments developed by March (1991) and the findings by Vermeulen and Barkema (2001) and Capron and Mitchell (1998), which suggest that acquisitions can be employed as a means of explorative learning that revitalizes a firm and enhances its knowledge base. Whether acquisitions actually meet this objective is of course a separate matter which involves looking at the post-acquisition impacts.

Third, we find that, controlling for a firm's commitment to R\&D and its R\&D productivity, firms acquiring private targets and subsidiaries tend to have a significantly larger stock of knowledge, which is proxied empirically by the Patent Stock (Hypothesis 3). Therefore, the evidence is consistent with the argument that a large stock of knowledge will predispose firms to undertake acquisition because they perceive that they have the necessary absorptive capacity to identify "appropriate" acquisition targets and to fully exploit their innovative potential (Cohen \& Levinthal, 1989, Makadok, 2001). This finding is also consistent with evidence from research on corporate venturing for the existence of a positive relationship between a firm's absorptive capacity and the level of its equity investments in new ventures (e.g. Dushnitsky \& Lenox, 2005).

Overall, our findings suggest that firms acquiring private firms and former subsidiaries have a low commitment to internal $R \& D$, low $R \& D$ productivity and a large stock of knowledge. Interestingly, the findings that R\&D productivity is low but the stock of knowledge is high before acquisition, indicate that the firm has been involved in an exploitation process but the effectiveness of this strategy is declining. It is then that high technology firms can turn to acquisitions to source new knowledge and they adjust accordingly their commitment to internal R\&D. On the basis of our findings, we conclude that acquisitions of privately held targets and former subsidiary units are a viable R\&D strategy for large high technology firms with relatively low levels of internal R\&D which seek to offset low R\&D productivity by exploring a range of potential future innovation trajectories in new and smaller business units.

The finding that the hypothesized relationships hold only for private targets and former subsidiaries is consistent with theories that emphasize the relative advantages of different organizational forms in the innovation process, which

\footnotetext{
${ }^{14}$ Their sample includes acquisitions which are part of our sample, and we find that our results continue to hold for the subsample of US firms active in electronic and electrical equipment.
} 
seem to be accounted for in the formulation of high technology firms' R\&D strategies (e.g. Williamson, 1975; Zenger, 1994). It is also consistent with evidence that technological entities tend to respond to low R\&D productivity by shifting their focus to scientific knowledge (Makri \& Lane, 2007), implying that acquirers are more likely to look for small science-based start-ups. More generally, it seems that there exists a market for small innovative business units that supplements other forms of technology markets, such as patent licensing or contract research (Grandstrand \& Sjolander, 1990). The advantage of this market is that it is relatively better suited for the transfer of tacit and socially embedded knowledge. Our findings about this group of acquisitions are consistent with empirical evidence reported by studies on comparable phenomena. For instance, Dushnitsky and Lenox (2005) find evidence that firms rely heavily on equity investments in entrepreneurial start-ups in order to source technological knowledge, whilst Puranam et al. (2003) find that large established IT firms use "technology-grafting" acquisitions of small private firms as a means of shortening time-to-market and strengthening their future product pipelines. We conjecture that the inability to identify firms acquiring public targets on the basis of their innovation characteristics is due to the greater complexity of factors affecting large acquisitions which include multiple motives - such as to rationalize costs, exploit economies of scale and scope, and increase market power-which are not primarily relevant in relation to the much more numerous and smaller acquisitions of non-public targets.

Our findings raise two interesting questions that deserve priority in setting the future research agenda. First, although our study provides evidence consistent with the view that high technology firms carry out acquisitions in an attempt to source externally technological knowledge, it could not inform whether these expectations are successfully materialized. Additional work is needed to establish whether the objectives of technology driven acquisitions are actually met and whether these acquisitions enhance the future R\&D capability of the acquirer. Second, our findings highlight the need to investigate the supply side of acquisitions. Further work should be conducted to uncover the innovative resources and capabilities of the business units that are targeted in such acquisitions. The restrictions imposed by data availability problems on private firms and former subsidiaries could be addressed by employing a small sample of carefully selected cases and qualitative research methods. Uncovering the innovative characteristics of the firms acquired will enable a deeper understanding of the role that acquisitions play as part of high technology firms' innovation strategy.

\section{References}

Ahuja, G., \& Katila, R. (2001). Technological acquisitions and the innovation performance of acquiring firms: A longitudinal study. Strategic Management Journal, 22, 197-220.

Ahuja, G., \& Lampert, C. M. (2001). Entrepreneurship in the large corporation: A longitudinal study of how established firms create breakthrough inventions. Strategic Management Journal, 22, 521-543.

Andrade, G., \& Stafford, E. (2004). Investigating the economic role of mergers. Journal of Corporate Finance, 10, 1-36.

Ang, J., \& Kohers, N. (2001). The take-over market for privately held companies: The US experience. Cambridge Journal of Economics, 25, $723-748$.

Archibugi, D. (1992). Patenting as an indicator of technological innovation. Science and Public Policy, 19, 357-368.

Arora, A., \& Gambardella, A. (1990). Complementary and external linkages: The strategies of the large firms in biotechnology. Journal of Industrial Economics, XXXVIII, 361-379.

Arora, A., \& Gambardella, A. (1994). Evaluating technological information and utilising it: Scientific knowledge, technological capability and external linkages in biotechnology. Journal of Economic Behaviour and Organisation, 24, 91-114.

Barney, J. B. (1991). Firm resources and sustained competitive advantage. Journal of Management, 17, 99-120.

Beck, N., Katz, J. N., \& Tucker, R. (1997). Beyond ordinary logit: Taking time seriously in binary time-series-cross-section models. California Institute of Technology. Social Science Working Paper, 1017.

Benou, G., \& Madura, J. (2005). High-tech acquisitions, firm specific characteristics and the role of investment bank advisors. Journal of High Technology Management Research, 16, 101-120.

Blonigen, B. A., \& Taylor, C. T. (2000). R\&D intensity and acquisitions in high-technology industries: Evidence from the US electronic and electrical equipment industries. The Journal of Industrial Economics, XLVIII, 47-70.

Bloom, N., \& Van Reenen, J. (2000). Real options, patents, productivity and market value: Evidence from a panel of British firms. The institute for fiscal studies WP 00/21.

Bresman, H., Birkinshaw, J., \& Nobel, R. (1999). Knowledge transfer in international acquisitions. Journal of international Business Studies, 30, 439-462.

Brown, S. L., \& Eisenhardt, K. M. (1997). The art of continuous change: Linking complexity theory and time-paced evolution in relentlessly shifting organizations. Administrative Science Quarterly, 42, 1-34.

Capron, L., \& Mitchell, W. (1998). Bilateral resource redeployment and capabilities improvement following horizontal acquisitions. Industrial and Corporate Change, 7, 453-484. 
Cassiman, B., Colombo, M., Garonne, P., \& Veugelers, R. (2005). The impact of M\&A on the R\&D process. An empirical analysis of the role of technological and market relatedness. Research Policy, 34, 195-220.

Chakrabarti, A., Hauschildt, J., \& Suverkrup, C. (1994). Does it pay to acquire technological firms? R\&D Management, 24, 47-56.

Chaudhuri, S., \& Tabrizi, B. (1999). Capturing the real value in high-tech acquisitions. Harvard Business Review, 77, $123-130$.

Chesbrough, H. W. (2003). Open innovation: The new imperative for creating and profiting from technology. Massachusetts: Harvard Business School Press.

Cohen, W. M., \& Levinthal, D. A. (1989). Innovation and learning: The two faces of R\&D. The Economic Journal, 99, $569-596$.

Comanor, W. S., \& Scherer, F. M. (1969). Patent statistics as a measure of technological change. Journal of Political Economy, 77, $392-398$.

Conn, C., Cosh, A., Guest, P., \& Hughes, A. (2005). The impact on UK acquirers of domestic, cross-border, public and private acquisitions. Journal of Business Finance \& Accounting, 32, 815-870.

Dierickx, I., \& Cool, K. (1989). Asset stock accumulation and sustainability of competitive advantage. Management Science, 35, $1504-1511$.

Dushnitsky, G., \& Lenox, M. J. (2005). When do firms undertake R\&D by investing in new ventures? Strategic Management Journal, $26,947-965$.

Ernst, H., \& Vitt, J. (2000). The influence of corporate acquisitions on the behaviour of key inventors. R\&D Management, 30, $105-119$.

Fey, C. F., \& Birkinshaw, J. (2005). External sources of knowledge, governance mode, and R\&D performance. Journal of Management, 31 , $597-621$.

Francis, J., \& Smith, A. (1995). Agency costs and innovation: Some empirical evidence. Journal of Accounting and Economics, 19, 382-409.

Freeman, C. (1982). The economics of industrial innovation (2nd ed.). London: Francis Pinter.

Fuller, K., Netter, J., \& Stegemoller, M. (2002). What do returns to acquiring firms tell us? Evidence from firms that make many acquisitions. Journal of Finance, LVII, 1763-1793.

Geroski, P., Van Reenen, J., \& Samiei, H. (1996). How persistently do firms innovate? CEPR Discussion Paper, 1433.

Granstrand, O., \& Sjolander, S. (1990). The acquisition of technology and small firms by large firms. Journal of Economic Behaviour and Organisation, 13, 367-386.

Greene, W. H. (1997). Econometric analysis (3rd ed.). New Jersey: Prentice-Hall Inc.

Griliches, Z. (1990). Patent statistics as economic indicators: A survey. Journal of Economic Literature, XXVIII, 1661-1707.

Gugler, K., Mueller, D. C., Yurtoglu, B., \& Zulehner, C. (2004). The determinants of mergers: An international comparison. University of Vienna working paper.

Hall, B. H. (1988). The effect of takeover activity on corporate research and development. In A. J. Auerbach (Ed.), Corporate takeovers: Causes and consequences (pp. 69-100). Chicago: University of Chicago Press.

Hall, B. H. (1990). The manufacturing sector master file, 1959-1987. NBER Working Paper W3366.

Hall, B. H. (1999). Mergers and R\&D revisited. Prepared for the quasi-experimental methods symposium, econometrics laboratory, UC Berkeley.

Hall, B. H., Jaffe, A., \& Trajtenberg, M. (2001). The NBER patent citations data file: Lessons, insights and methodological tools. NBER Working Paper W8498.

Hall, B. H., \& Vopel, K. (1996). Innovation, market share, and market value. Prepared for the international conference on the economics and econometrics of innovation, Strasbourg, France: The European Parliament.

Haspeslagh, P. C., \& Jemison, D. B. (1991). Managing acquisitions: Creating value through corporate renewal. New York: Free Press.

Hitt, M. A., Hoskisson, R. E., \& Ireland, R. D. (1990). Mergers and acquisitions and management commitment to innovation in M-form firms. Strategic Management Journal, 11, 29-47.

Hitt, M. A., Hoskisson, R. E., Ireland, R. D., \& Harrison, J. S. (1991). Effects of acquisitions on R\&D inputs and outputs. Academy of Management Journal, 34, 639-706.

Hitt, M. A., Hoskisson, R. E., Johnson, R. A., \& Moesel, D. D. (1996). The market for corporate control and firm innovation. Academy of Management Journal, 39, 1084-1119.

Holloway C.A., Wheelwright S.C., \& Tempest N. (2004). Cisco Systems, Inc. Acquisitions integration for manufacturing. Case, Stanford University

Hsiao, C. (1986). Analysis of panel data. Cambridge: Cambridge University Press.

Inkpen, A. C., Sundaram, A. K., \& Rockwood, K. (2000). Cross-border acquisitions of US technology assets. California Management Review, 42, $50-71$.

Kim, D., \& Kogut, B. (1996). Technological platforms and diversification. Organization Science, 7, 283-301.

Kohers, N., \& Kohers, T. (2000). The value creation potential of high-tech mergers. Association for Management and Research, 56, 40-50.

Kohers, N., \& Kohers, T. (2001). Takeovers of technology firms: Expectations vs. reality. Financial Management, $30,35-54$.

Kogut, B., \& Zander, U. (1992). Knowledge of the firm, combinative capabilities and the replication of technology. Organization Science, 3 , 383-397.

Kogut, B., \& Zander, U. (1996). What firms do? Coordination, identity, and learning. Organization Science, 7, 502-518.

Leonard-Barton, D. (1992). Core capabilities and core rigidities: A paradox in managing new product development. Strategic Management Journal, $13,111-125$.

Makadok, R. (2001). Toward a synthesis of the resource-based and dynamic-capability views of rent creation. Strategic Management Journal, 22, $387-401$.

Makri, M., \& Lane, P. J. (2007). Responding to technological maturity: A socio-cognitive model of science and innovation in technological communities. Journal of High Technology Management Research, 18, 1-14.

March, J. G. (1991). Exploration and exploitation in organizational learning. Organization Science, 2, 71-87.

Mitchell, M. L., \& Mulherin, H. J. (1996). The impact of industry shocks on takeovers and restructuring activity. Journal of Financial Economics, 41 , $193-229$.

Odagiri, H. (2003). Transaction costs and capabilities as determinants of the R\&D boundaries of the firm: A case study of the ten largest pharmaceutical firms in Japan. Managerial \& Decision Economics, 24, 187-211.

OECD (1996). The knowledge-based economy. Paris: OECD. 
Palepu, K. G. (1986). Predicting takeover targets: A methodological and empirical analysis. Journal of Accounting and Economics, 8, 3-35.

Parhankangas, A., \& Arenius, P. (2003). From a corporate venture to an independent company: A base for a taxonomy for corporate spin-off firms. Research Policy, 32, 463-481.

Pidgeon, R. (1999). Patenting: Pitfalls and prizes. Chemistry in Britain, 35, $25-28$.

Poirier, D. J., \& Ruud, P. A. (1988). Probit with dependent observations. Review of Economic Studies, 55, 593-614.

Porrini, P. (2004). Alliance experience and value creation in high-tech and low-tech acquisitions. Journal of High Technology Management Research, $15,267-292$.

Powell, R. (1997). Modelling takeover likelihood. Journal of Business, Finance and Accounting, 24, 1009-1030.

Prabhu, J. C., Chandy, R. K., \& Ellis, M. (2005). The impact of acquisitions on innovation: Poison pill, placebo, or tonic? Journal of Marketing, 69, $114-130$

Puranam, P., Singh, H., \& Zollo, M. (2003). A bird in the hand or two in the bush? Integration trade-offs in technology-grafting acquisitions. European Management Journal, 21, 179-184.

Puranam, P., Singh, H., \& Zollo, M. (2006). Organizing for innovation: Managing the coordination-autonomy dilemma in technology acquisition. Academy of Management Journal, 49, 263-280.

Ragozzino, R. (2006). Firm valuation effects of high-tech M\&A: A comparison of new ventures and established firms. Journal of High Technology Management Research, 17, 85-96.

Ranft, A. L., \& Lord, M. D. (2000). Acquiring new knowledge: The role of retaining human capital in acquisitions of high-tech firms. Journal of High Technology Management Research, 11, 295-319.

Ranft, A. L., \& Lord, M. D. (2002). Acquiring new technologies and capabilities: A grounded model of acquisition implementation. Organization Science, 13, 420-441.

Scherer, F. M. (1997). Investing in technological innovation. Judge Institute of Management Studies Working Paper 08/97.

Schildt, H. A., Muala, M. V. J., \& Keil, T. (2005). Explorative and exploitative learning from external corporate ventures. Entrepreneurship Theory and Practice, 29, 493-515.

Smith, C. L., \& Warner, J. B. (1979). Bankruptcy, secured debt, and optimal capital structure: A comment. Journal of Finance, 34, $247-251$.

Steensma, K. H., \& Fairbank, J. F. (1999). Internalizing external technology: A model of governance mode choice and an empirical assessment. Journal of High Technology Management Research, 10, 1-35.

Vermeulen, F., \& Barkema, H. (2001). Learning through acquisitions. Academy of Management Journal, 44, 457-476.

Veugelers, R., \& Cassiman, B. (1999). Make and buy in innovation strategies: Evidence from Belgian manufacturing firms. Research Policy, 28, 63-80.

Weston, J. F., Chung, K. S., \& Siu, J. A. (1998). Takeovers, restructuring and corporate governance. New Jersey: Prentice-Hall.

Williamson, O. E. (1975). Markets and hierarchies: Analysis and antitrust implications. New York: Free Press.

Williamson, O. E. (1979). Transaction-cost economics: The governance of contractual relations. Journal of Law and Economics, 22, $233-261$.

Williamson, O. E. (1981). The economics of organization: The transaction cost approach. American Journal of Sociology, 87, $548-577$.

Wooldridge, J. M. (2002). Econometric analysis of cross section and panel data. Massachusetts: MIT Press.

Zenger, T. (1994). Explaining organizational diseconomies of scale in R\&D: Agency problems and the allocation of engineering talent, ideas, and effort by firm size. Management Science, 40, 708-729.

Zollo, M., \& Singh, H. (2004). Deliberate learning in corporate acquisitions: Post-acquisition strategies and integration capability in US bank mergers. Strategic Management Journal, 25, 1233-1256. 